\title{
THE EFFECT OF FAMILY LITERACY CULTURE ON STUDENT'S MOTIVATION IN ISLAMIC EDUCATION SUBJECT AT STATE SENIOR HIGH SCHOOL IN GARUT
}

\author{
Hilda Ainissyifa \\ Department of Islamic Education, Universitas Garut, Indonesia \\ Jl. Raya Samarang No. 54A, Garut 44151, Indonesia \\ Email: hildaainissyifa@uniga.ac.id \\ Riska Amelia \\ Department of Islamic Education, Universitas Garut, Indonesia \\ Jl. Raya Samarang No. 54A, Garut 44151, Indonesia \\ Email: riskadade13@gmail.com
}

Received: 01, 2018. Accepted: 01, 2019. Published: 01, 2019.

\begin{abstract}
The environment is believed to have a strong effect on the learning process of students, including the family's influence. This study is aimed to examine the influence of family literacy culture on student learning motivation in Islamic education subject. This study applied the associative method with inferential statistical analysis. The population of this study covers 484 students of class X at State Senior High School in Garut District, Indonesia, while the number of research samples comprises 83 respondents. Data measurement in this research uses ordinal data with Likert Scale measurement. The analysis methods include regression analysis, correlation coefficient, the coefficient of determination, and hypothesis testing. The results showed that the culture of family literacy had a positive and significant impact on students' learning motivation in the Subject of Islamic Education
\end{abstract}

Keywords: Culture, Family, Literacy, Learning, Motivation

\begin{abstract}
ABSTRAK
Lingkungan diyakini memberikan pengarub yang kuat terhadap proses pembelajaran siswa, termasuk di dalamnya pegarub keluarga. Penelitian ini bertujuan untuk meneliti tentang pengarub budaya literasi keluarga terbadap motivasi belajar siswa pada mata pelajaran pendidikan Agama Islam. Metode yang digunakan dalam penelitian ini adalah metode asosiatif dengan analisis statistik inferensial. Populasi penelitian ini adalah siswa Kelas X pada sebuah Sekolah Menengah Atas Negeri di Kabupaten Garut, Indonesia, dengan jumlah populasi sebanyak 484 orang, adapun jumlah sampel responden penelitian sebanyak 83 orang. Pengukuran data pada penelitian menggunakan data ordinal dengan pengukuran skala likert. Metode analisa yang digunakan, diantaranya analisis regresi, koefisien korelasi, koefisien determinasi, dan pengujian hipotesis. Hasil penelitian menunjukean bahwa budaya literasi keluarga berpengaruh secara positif dan signifikan terhadap motivasi belajar siswa pada Mata Pelajaran Pendidikan Agama Islam.
\end{abstract}

Kata Kunci: Belajar, Budaya, Keluarga, Literasi, Motivasi

\section{INTRODUCTION}

Islamic education is a conscious, planned, and systematic attempt to nurture and develop a human personality, within the spiritual and physical aspect, and takes place in stages by the Islamic teachings (Mulyana, 2009; Tafsir, 2014; Ramdhani, et al., 2015). The general goal of Islamic Education is to shape a perfect Muslim, a pious man, a faithful man, and/ or a man who worships Allah (Tafsir, 2014). In achieving the goal of Islamic education, there required good cooperation between the educational path, from which learners have to experience the process of education in the family. The educational path is a vehicle through which learners 
develop their potential in an educational process appropriate to the educational objectives (Helmawati, 2014).

Humans have potential from their birth in the world. The potential is a power that will make a man grow as a great person and develop to get perfect. It is also a strength and ability to adapt, absorb, and assimilate everything around him. Therefore, this potential must be developed and understood by parents and educators, to get treatment or guidance towards a comprehensive development, comprising various aspects of physical, emotional, religious, intellectual, and social development that should give proportional attention. Moreover, failure to pay attention to the growth of those aspects will lead to the failure to respond to the hybrid generation, good generation, who have a strong, comprehensive and mature personality. Successful attention to all aspects of this development will have an impact on the success of children in the future, both in social and academic fields (Hasbiyalloh \& Sulhan, 2015).

In the family environment, the child is the mandate of Allah. The essence of accountability is providing education for children in the family (Tafsir, 2014), and giving a good environment for child education. God says that parents must protect their family from hell by education, as stated in the QS. At-Tahrim [66]: 6. The verse illustrates that da'wah and education should start at home. In this regard, parents are responsible for the children as well as their spouses as they are responsible for their deeds. In QS. Luqman [31]: 13 it is explained that family, especially parents, are obliged to educate or teach their children.

Family in the educational process gives a strong influence on a person's learning behavior. It assumed that reading habit of a family would increase the learning motivation. Various studies have proven that children raised in reading family, in which parents pay attention and encourage children's interest and curiosity, generally have more advancement at school (Tampubolon, 1993). Also, the creation of reading family will increase children's motivation because they learn from the surrounding life, especially parents as the closets people to the children. There is an imitation nature in a child that can be a positive thing to be an extrinsic motivation for the child (Laila, 2016).

The topic of the relationship between the culture of family literacy and students' learning motivation is under research. This study aims to examine the influence of family literacy culture on student learning motivation of Islamic religious education subjects.

\section{METHOD}

Research is a process of collecting, analyzing, and translating information and/ or data systems to increase understanding of a particular phenomenon (Ramdhani, 2013). The research uses a scientific method by way of data collection and analysis test of hypothesis (Ramdhani \& Ramdhani, 2016). This study employed the associative method with inferential statistical analysis. The population of this study covers 484 students of Class X SMAN 1 Garut, Indonesia, while the number of research samples comprised 83 respondents. Sampling was done randomly, so the entire population had the same possibility and opportunity to become sample respondents.

To see the objective condition of the research object, this study determines the operationalization of research variables, which are structured to facilitate the steps in collecting and gathering the obtained data from the respondents by the theory, concept, proposition, and assumption of the defined variables. The operationalization of research variables presented in Table 1. 
Table 1: Variables operationalization

\begin{tabular}{|c|c|c|}
\hline Variable & Dimension & Indicator \\
\hline \multirow{9}{*}{$\begin{array}{l}\text { The culture of Family } \\
\text { Literacy Culture (X) }\end{array}$} & \multirow[t]{4}{*}{ 1. Reading } & a. Interest and reading frequency \\
\hline & & $\begin{array}{l}\text { b. Finding or obtaining information } \\
\text { from text }\end{array}$ \\
\hline & & $\begin{array}{l}\text { c. Understanding the meaning of the } \\
\text { text }\end{array}$ \\
\hline & & $\begin{array}{l}\text { d. Applying or practicing the essence of } \\
\text { reading content }\end{array}$ \\
\hline & \multirow[t]{2}{*}{ 2. Writing } & $\begin{array}{l}\text { a. Being creative to explore ideas in } \\
\text { written language }\end{array}$ \\
\hline & & $\begin{array}{l}\text { b. Producing work in the form of essay } \\
\text { or writing }\end{array}$ \\
\hline & \multirow[t]{3}{*}{ 3. Text discussion } & a. Discussing a problem in the text. \\
\hline & & b. Sharing information from text \\
\hline & & $\begin{array}{l}\text { c. Expressing opinions to each other in } \\
\text { discussions about books and other } \\
\text { texts }\end{array}$ \\
\hline \multirow[t]{6}{*}{$\begin{array}{l}\text { Student's learning motivation } \\
\text { (Y) }\end{array}$} & \multirow[t]{2}{*}{$\begin{array}{l}\text { 1. Desire and wish to } \\
\text { succeed }\end{array}$} & $\begin{array}{l}\text { 1. The motive to succeed in doing } \\
\text { something and job or motive to } \\
\text { obtain perfection }\end{array}$ \\
\hline & & $\begin{array}{l}\text { 2. The effort to complete task } \\
\text { thoroughly, without delaying work }\end{array}$ \\
\hline & \multirow[t]{2}{*}{$\begin{array}{l}\text { 2. Encouragement } \\
\text { and need in } \\
\text { learning }\end{array}$} & $\begin{array}{l}\text { 1. Encouragement of avoiding failure } \\
\text { comes from the fear of failure }\end{array}$ \\
\hline & & $\begin{array}{l}\text { 2. Attempt to achieve learning } \\
\text { objectives with maximum effort }\end{array}$ \\
\hline & \multirow{2}{*}{$\begin{array}{l}\text { 2. Hope or dream of } \\
\text { the future }\end{array}$} & 1. Showing good performance \\
\hline & & $\begin{array}{l}\text { 2. Having confidence that people are } \\
\text { affected by their feelings of the image } \\
\text { of the action outcome }\end{array}$ \\
\hline
\end{tabular}

Data measurement in this study uses ordinal data with Likert Scale measurement. While analytical method includes regression analysis, correlation coefficient, determination coefficient, and hypothesis testing. The application of regression analysis aims to estimate the effect of one variable on the other variable. The analysis of correlation coefficient is used to state the relationship between independent variable and dependent variable. Determination coefficient $\left(\mathrm{r}^{2}\right)$ essentially measures the extent of the model's ability to explain the variation of the dependent variable (Ramdhani \& Ramdhani, 2016). While the hypothesis testing in this study is "the influence of Family Literacy Culture on student learning motivation in Islamic education subjects." To identify whether an independent variable influences the dependent variable, the t-test is done. To strengthen the results of the study, research findings verification is done through observation, interview, and literature studies.

\section{RESULTS AND DISCUSSION}

\section{The Effect of Family Literacy Culture on Student's Motivation}

This study examines the empirical facts about the influence of family literacy culture on student learning motivation in Islamic education subjects in grade X students of State Senior High School at Garut District. Schematically, the effectual causal relationship occurs between 
variables in the research paradigm. To facilitate the analysis, the modeling of the research focus in the form of a research paradigm. Model is a simplification from the real world that can show relationships between variables (Amin \& Ramdhani, 2006).

The results of the initial observations of researchers on several families or guardians of students of SMAN 1 Garut, found the fact that family/guardians of students of SMAN 1 Garut had a good family literacy culture and it was characterized by a culture of love of reading. The books they read included books on general knowledge, history, research journals, political science, stories and so on. Religious books were rarely chosen as the main reading material. The culture of literacy in the family, generally carried out independently, so that rarely fellow family members gather and discuss the books they read together.

Further analysis is carried out using an analysis of effectual causal. The analyzed research paradigm is shown in Figure 1.

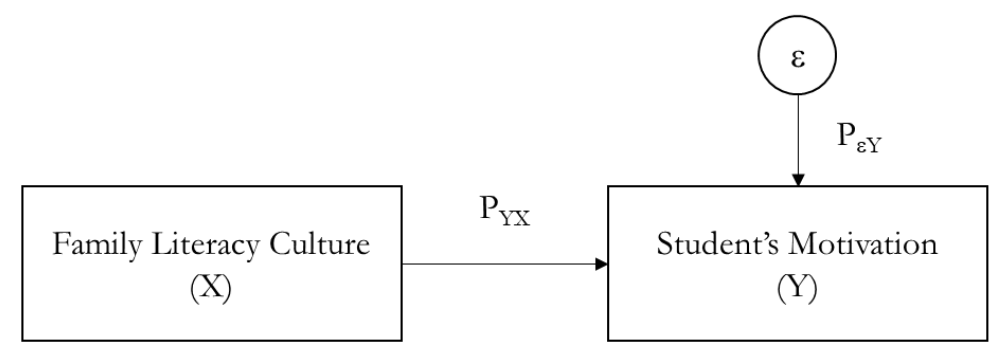

Figure 1: Model of Research Paradigm

The research findings present the result of statistical calculation, which can be represented in tabular form, as shown in Table 2.

Table 2. Calculation Result of Statistical Analysis

\begin{tabular}{lcl}
\hline \multicolumn{1}{c}{ Testing } & Result & \multicolumn{1}{c}{ Description of Analysis Result } \\
\hline $\begin{array}{l}\text { Regression } \\
\text { analysis }\end{array}$ & $\check{Y}=4.253+0.648 \mathrm{X}$ & $\begin{array}{l}\text { The increasing value of family literacy culture } \\
\text { variables will have a positive effect on the value } \\
\text { of student learning motivation variable }\end{array}$ \\
\hline $\begin{array}{l}\text { Correlation } \\
\text { coefficient }\end{array}$ & 0.770 & $\begin{array}{l}\text { The variable of family literacy culture has a strong } \\
\text { relationship with the variable value of student's } \\
\text { learning motivation }\end{array}$ \\
\hline $\begin{array}{l}\text { Coefficient of } \\
\text { determination }\end{array}$ & 0.593 & $\begin{array}{l}\text { The variable of family literacy culture can state } \\
\mathbf{5 9 . 3 \%} \text { to student's motivation variable }\end{array}$ \\
\hline $\begin{array}{l}\text { Hypothesis testing } \\
\text { (t-test) }\end{array}$ & $\begin{array}{l}\mathrm{t}_{\text {tabel }}=1.664 . \\
\mathrm{t}_{\text {stat }}=10.862\end{array}$ & $\begin{array}{l}\text { The variable of literacy culture has a significant } \\
\text { influence on the variable of student learning } \\
\text { motivation }\end{array}$ \\
\hline
\end{tabular}

Note: $\quad \mathrm{X} \quad$ : variable of family literacy culture

$\mathrm{Y} \quad$ : variable of student learning motivation

The resume of statistical analysis above can be stated that the culture of family literacy had a positive and significant impact on student learning motivation. This study is a research in the field of education. Educational science was used as the unit of analysis to study the process of influence between students and educators in various educational situations to achieve educational goals.

\section{Family Literacy Culture in Islamic Education Subject}

Culture is a system of values, beliefs, assumptions, or long-standing norms, agreed upon, and followed by certain communities as a code of conduct and problem-solving of their organization (Ramdhani, et al., 2017; Sutrisno, 2010; Ainissyifa \& Hamdani, 2012). Furthermore, Robbins and Coulter reveal that organizational culture is the values, principles, 
traditions, and ways of work shared by members of the organization and affect the way of their act (Robbins \& Coulter, 2010). Culture is the collective programming of the human mind that distinguishes a group of people from other groups. Culture is said to be the general values and behaviors of a group that affects the behavior of its members (Hofstede, 1980). While Hughes explained that organizational culture is a "normative adhering" which is an agreement and unifying organization. The result is an independent social system, consisting of values, symbols, rituals, myths that have a strong influence on the behavior of its members (Hughes, 1996). Another definition states that organizational culture is history and reflects the beliefs of the owners of organization and an individual adhering, whose values are maintained by members of the organization and they are difficult to change (Alvesson, 2002).

In line with the opinions of Davis and Newstrom (2004), behavior is influenced by several things, based on observations at the research object, behavior can be influenced by four key forces that tend to influence the behavior of the organization in which the organization operates, namely: (1) people; (2) structure; (3) technology, and (4) environment (Davis \& Newstrom, 2004).

Based on interviews, the research founded the fact that there was an agreement that family culture refers to the unity of the system of cultured meaning embraced by family members. This cultured meaning system, if observed more closely, is a major set of characteristics valued by family members. The family culture model assumes that beliefs, values, and ideology are in the family's parents. Children generally maintain certain preference ideas and values that affect how they perceive the behavior of other family members. These norms become a shared tradition communicated in families. The family articulates values, to give shape and meaning to the activities of family members who state that the behavior carried out is decent and good.

Morgan (1997) argues that the focus of the family as an organization as a cultural phenomenon leads to the structure of meaning sharing. The family is a social reality system that is built from the many thoughts of family members when they are in the structure and is supported by the relationships and regulations that it creates (Morgan, 1997). Every family has a culture (a set of norms and values) that collectively guides the behavior of family members.

This research discusses literacy culture in family units. Moreover, literacy can be interpreted as a reading and writing ability. But now, literacy has a broad meaning, so literacy does not have a single meaning, but it comprises multiple meanings (multi-literacies). There is a variety of literacy, such as computer literacy, media literacy, technological literacy, economic literacy, information literacy, and even moral literacy. So, literacy can be defined as technology literacy, information literacy, critical thinking, sensitive to the environment, even political sensitivity. A person is said to be literate if he can understand something because of reading the right information and doing something based on his understanding of the reading content (Permatasari, 2015). While the literacy meaning to the Ministry of Education and Culture is the ability to access, understand, and use information intelligently (Kementerian Pendidikan dan Kebudayaan, 2016) From both definitions, the author inferred that literacy is a reading activity with the ability to understand the reading contents, and use the understanding outcome intelligently.

The dependent variable in this study is family literacy culture. Family is a small group that has a leader and members, has tasks and work division, rights and obligations for each member. The family is the first and foremost place where children learn. From their families, children learn the nature of beliefs, noble traits, communication, and social interaction, as well as life skills (Helmawati, 2014). From some meanings above, the author concludes that the 
culture of family literacy is a habit of thinking followed by a reading process which ends with a work resulted from the thought and understanding intelligence, performed by a family.

The results of this research observation supported the opinion of Kern (2000), where the results of the study indicate that there are seven principles of literacy education (Kern, 2000), namely:

1. Literacy involves interpretation. The writer and reader participate in the act of interpretation, namely: the author interprets the world (events, experiences, ideas, feelings, etc.), and the reader then translates the author's interpretation in his conception of the world.

2. Literacy involves collaboration. There is a collaboration between the writer and the reader. The cooperation in question is to achieve a common understanding. The author decides what must be written or that need not be written based on their understanding of the reader. While readers devote their motivation, knowledge, and experience to make the author's text meaningful.

3. Literacy involves conventions. People reading and writing or listening and speaking are determined by cultural conventions/ agreements that develop through use and modified for individual purposes. The Convention here includes the rules of language both oral and written.

4. Literacy involves cultural knowledge. Reading and writing have a function in understanding certain systems of attitudes, beliefs, habits, ideal, and values. People who are outside a cultural system will be vulnerable or at risk of misunderstanding if they interpret them.

5. Literacy involves solving problems. Words are always attached to the linguistic context and the situation that surrounds it, so the act of listening, speaking, reading, and writing involves trying to imagine the relationships between words, phrases, sentences, units of meaning, text, and letters. The effort to imagine or think about or consider this is a form of problem-solving.

6. Literacy involves reflection. Readers and writers think of language and its relationships with the world and themselves. After they are in a communication situation, they think about what they have written, how to write it, and why to write it.

7. Literacy involves the use of language. Literacy is not limited to language systems (verbal/ written) but requires knowledge of how the language is used both in oral and written contexts to create a discourse.

This study discusses the family of students. The family is a small group that has leaders and members, has a division of tasks and work, as well as rights and obligations for each member. It is the first and foremost place where children learn. From family, they learn the nature of beliefs, noble traits, communication and social interaction, and life skills (Helmawati, 2014). It is a social foundation. Prosperous families under marriage ties become the main pillars of social building foundations (Hasbiyallah \& Sulhan, 2015).

Reading family is a family that lives in a good literacy culture, which, in turn, reading and understanding the reading content is a necessity. All members of a family with literacy culture will enjoy reading and discuss it (Sareb, 2008). Based on the above meaning, the culture of family literacy operationalized in the following dimensions: a) Reading, b) Writing, c) Discussing the reading content.

From the religious perspective, reading is the characteristic of faith, as stated in QS. AlBaqarah (2): 121 a true reading, with a high frequency, understanding the essence of Quranic messages, and practicing their values. It is not sufficient for people to only read, memorize Qur'an, they, however, must practice its teaching and values in everyday life. 
Islamic education has a direct bond with Islamic values and teachings that govern all aspects of its life. When the definitions of education associated with Islamic education, it will be known that Islamic education emphasizes more on the balance and harmony of the development of human life. Islamic education defined as an effort to change individual behavior in his personal life or social life, and life in the surrounding environment through the process of education. The change based on Islamic values, namely values that give birth to sharia norms and akblak karimah (Arifin, 2016).

Reading is a very important skill that everyone has to master and understand. It is a process done and used by the reader to obtain a message, which would be conveyed by the author through written language (Tarigan, 2008). It is an interactive activity to gain and understand the meaning in written language. Furthermore, it said that reading is a process done and used by readers to get the message conveyed by the author (Somadyo, 2011).

Reading has some objectives (Tarigan, 2008):

1. Reading to find or know the discoveries. The activity is called reading to obtain details or facts (reading for details or facts).

2. Reading to know a good or interesting topic. Such reading is called reading to obtain the main ideas (reading for mains ideas).

3. Reading to know what happens to each section of the story. Such reading is called reading to know the order or sequence of a story (reading for sequence or organization).

4. Reading to sum up the content or for inference purpose.

5. Reading to classify

6. Reading to evaluate a particular character in a story.

7. Reading to compare and contrast two different stories (reading to evaluate).

Thus, the core purpose of reading is to seek and obtain information, including the content of reading the text and various other objectives that stated above.

In reading activities, the reader should be able to: (1) observe the symbols presented in the text, (2) interpret the symbol or word, (3) follow the printed word in a linear, logical, and grammatical pattern; (4) connect words with direct experience which gives meaning to the word, (5) make interference (conclusion) and evaluates reading material, (6) recall that learned material in the past and inflames new ideas and facts of the text, (7) know the relationship between symbol and sounds, and the interconnections expressed in the text, and (8) divide the reading attention (Harjasujana \& Damaianti, 2003).

The cultural dimension of family literacy after reading is writing. Writing is a communication activity in the form of written messages (information) delivery to other people by using written language as a tool or media. It involves several elements, namely: the author as a messenger, the content of a writing, the channel or the media, and the reader. It is a creative process of exploring ideas in the form of written language intended, for example, to tell, reassure, or entertain. The result of the creative process can be called essay or writing (Dalman, 2012).

Writing is making symbols or graphs depicting a language that a person understands so that someone else or others can read the graphic symbols if they understand the language and graphic picture (Tarigan, 2008). Based on the above meaning the author concludes that writing means an activity of exploring thoughts and ideas in writing and it becomes work of essay or writing.

Writing has a lot of benefits to gain in this life (Dalman, 2012), namely:

1. Increasing intelligence

2. Developing initiation and creativity

3. Growing courage

4. Encouraging will and ability to collect information. 
The discussion is a process of two or more individuals' perspectives who interact verbally and face to face with a defined goal or objective through sharing information, defending opinions, or problem-solving. While the discussion method is a way to hold a scientific discussion to collect opinions, make conclusions, or arrange various alternative solutions to a problem (Taniredja, et al., 2011). It can be concluded that the discussion is a process of sharing thoughts that are regular and directed. While discussing means an activity to discuss a problem, share information and express mutual opinions in the discussion.

Reading material is a good article in the form of sentences, paragraphs or articles of both readable scientific and non-scientific material and provide information from the reading contents. Based on this understanding, the authors can conclude discussing the reading material is an activity to discuss a problem, share information and express mutual opinions in books and other materials.

\section{Student's Motivation}

The power that drives one's activity is called motivation, which indicates a condition within a person that encourages or drives him to accomplish an act of meeting a goal (Sukmadinata, 2011). Motivation is a power to change within a person characterized by effective encouragement and reactions to achieve the goal (Nurfajrinah, et al., 2017; Soemanto, 2012). It is interpreted as power (energy) of a person that can create persistence and enthusiasm in carrying out an activity, either deriving from within the individual (intrinsic motivation) or from outside the individual (extrinsic motivation) (Mulyana, 2009). To sum up, motivation is the impetus of individual power that encourages him to make efforts in achieving a goal.

Furthermore, learning is a basic process of human life development. By learning, people make individual qualitative changes so that their behavior develops (Soemanto, 2012). Learning is modifying or reinforcing behavior through experience. It is defined as the modification or strengthening of behavior through experiencing (Hamalik, 2010). It is a change in personality, manifested as new response patterns in the form of skill, attitude, habit, knowledge, and capability (Sukmadinata, 2011). It is a process that produces a change of selfdevelopment in the form of knowledge, attitude, and skills. Based on the above understandings, it inferred that the notion of learning motivation is the impetus of individual forces that encourage him to make an effort in achieving an objective through the process that produces changes in self-development of knowledge, attitude, and skills.

In operating variables, the dimensions of learning motivation classified into (Uno, 2011):

1. Desire and will to succeed

2. Encouragement and need for learning

3. Hope or dream of the future

4. Appreciation in learning

5. Interesting activities in learning

6. A conducive learning environment that allows a student to learn well.

Based on the statement on the learning motivation dimension, this study limits it by the related dimension to this research, namely: a) desire and will to succeed, b) encouragement and needs for learning, c) hope or dream of the future.

The desire and will to succeed in learning and everyday life are generally said achievement motive, as a motive to succeed in performing a task and job or motive to gain perfection. This motive is a part of human personality and behavior, something that comes from "within" the human (Uno, 2011). Achievement motive is a learnable motive. Thus it can be improved and developed through the learning process. A person who has high achievement motive tends to complete the task completely, without delaying his work. The completion of this task is not an outward force, but a personal endeavor (Uno, 2011). 
The completion of a task is not always motivated by achievement motive or a will to succeed, one sometimes completes his job as good as a person with a high-achieving motive, because he attempts to avoid a failure deriving from the fear of failure (Uno, 2011).

It seems that a student may work diligently because if he does not finish his job well, he will get embarrassed before his lecturer, or fear his friends' banter, or even his parents' punishment. The above description indicated that the "success" of students driven outside encouragement or stimuli. The expectation based on the belief that someone is affected by his feeling on the image of his actions, for example, one who wants to get promotion will show good performance if he considers that high performance is recognized and rewarded in promotion (Uno, 2011).

The process of family education influenced by several factors, one of them is a method (Helmawati, 2014). The method is a way or tools through which the goal of education can be achieved by students. Without the proper method of educational transformation, the students will not optimally catch the learning material even though the teachers are very clever and the expert in their field.

One of the proper methods applied in family education is an exemplary method. The definition of exemplary/al-uswah is a state when a man follows others, whether regarding kindness, badness, evil, or apostasy (Arief, 2003). In everyday interaction, children imitate what their parents do (Helmawati, 2014). Accordingly, positive and good habits should be adapted to be a culture or daily custom so that children will get used to doing good deeds. The results of this study show that the students' parents have good habits that are followed by their children (students). In this regard, the good habit done every day is the culture of family literacy.

In general, motivation is divided into two major parts, namely: intrinsic and extrinsic motivation (Uno, 2011). The basic, personal motives commonly arise in individual action after being "shaped" by environmental influences. Therefore, the individual motives for doing something, such as the motive for good learning can be developed, improved, or altered through environmental influences.

\section{Family Literacy Culture and Student's Motivation}

The culture of family literacy is a family that lives in a good literacy culture, which in the end, reading, and understanding the contents of reading is a necessity. Families who have a literacy culture of all members will enjoy reading, then discuss it (Sareb, 2008). They gain reading benefits because they have a literary culture, as follows:

1. Reading skills in children is important as a key to achieving success both at school and at work.

2. Reading can provide pleasure and hone their imagination and open the door for children to enter a new world.

3. Reading (and writing) paves the way for language mastery and communication.

This study examines the culture of family literacy. Based on research findings, this study uses Sareb (2008) paradigm, who presents several steps that can take to build a culture of family literacy, namely:

1. Controlling tv watching hours. Start by agreeing to the hours of watching television.

2. Teaching by example. If you choose to book, newspapers, and magazines, if you read and enjoy it every day, undoubtedly over time your family members do like you.

3. Reading activity together. Find the time, or agree when to read together. A family with a reading culture has a home library. Each is busy with reading, but one day there is a book that can be read together and enjoyed together, then discussed. In addition to increasing knowledge, reading together can also tighten the family straps and build closeness with each other. 
4. Building a home library. The home library will automatically encourage and create a reading culture. If there are still very few references, look for books to fill libraries that are also suitable for children. For example, information books about health, hobbies, or books with lots of pictures and colors. From the joy of cheerful books, children will turn to serious books.

5. Delivering and conditioning love books for toddlers. You can read the book to him/ her:

a. Choosing books that are small, thin, and easily understood by children.

b. Telling them the purpose of the picture.

c. Singing them a text to pay attention to children.

d. Playing the cover or tongue of the book.

e. Helping your children touch and feel the texture of the book.

If the steps and tricks are carried out, the culture of literacy, especially the reading culture in the family, will be well developed.

Relating to motivation as part of the research variable, motivation basically can help in understanding and explaining individual behavior, including the behavior of individuals who are learning. According to Uno (2016), there are several important roles of motivation in learning and learning, including:

1. The role of motivation determines the strengthening of learning. Motivation can play a role in strengthening learning if a child who is learning is faced with a problem that requires solving, and can only solve thanks to the help of the things he has gone through. For example, a child will solve mathematical material with the help of logarithmic tables. Without the help of the table, the child cannot complete math assignments. In that connection, children try to find a math table book. Efforts to find a mathematical table are motivational roles that can lead to strengthening learning. The above events can be understood that something could be a learning reinforcement for someone if he has the motivation to learn something. Motivation can determine things that can strengthen learning.

2. The role of motivation in clarifying learning goals. The role of motivation in clarifying learning objectives is closely related to the meaning of learning. Children will be interested in learning something if what they have learned is at least known or enjoyed by the child. For example, they will be motivated to learn electronics because the goal of electronic learning can improve their ability in the electronic field. On one occasion, for example, the child was asked to fix the radio, with his knowledge and experience in the electronic field, the radio became good after repairing it. From that experience, children are increasingly motivated to learn.

3. Motivation determines to learn persistence. A child who has been motivated to learn something will try to learn it well and diligently, in the hope of getting good results. Motivation to learn causes, someone, to study hard. Conversely, if a person is lacking or does not have the motivation to learn, then he does not last long. He is easily tempted to do other things outside the learning process. This means that motivation influences are learning resistance and perseverance.

This study provides a focus of discussion on the object of Islamic Religious Education. The scope of the subjects of Islamic religious education as a whole in the scope of the Qur'an and hadith, faith, morals, fiqh/ worship, and history, as well as illustrating that the scope of Islamic Religious Education includes the realization of harmony and balance of human relations with Allah, himself, fellow human beings, other creatures, and the environment (bablun minalläh wa hablun minannās) (Majid \& Andayani, 2004).

The aim is the result intended in a business or activity. Islamic religious education in schools/ madrasah aims to foster and enhance faith through the giving and fertilizing of 
knowledge, appreciation, practice, and experience of students about the religion of Islam so that it becomes a Muslim man who continues to grow in terms of faith, piety, nation, and state, and to be able to continue at a higher level education (Majid \& Andayani, 2004). The educational objectives in question are changes in three fundamental areas, namely:

a. Individual goals. Individual goals relating to individuals, lessons with their personalities, and what is related to these individuals, such as desired changes in behavior, activities, and achievements, desired growth in their personalities, and in preparations that must be prepared by them in the life of the world and the hereafter.

b. Social objectives. Social objectives related to people's lives and the overall behavior of the general public, as well as about desired changes related to life and growth enrich the desired experience and progress.

c. Professional aims. Professional aims related to education and teaching as a science, as an art, as a profession, and as an activity among community activities.

The knowledge taught in Islamic education is oriented to strengthen the value of faith, knowledge, and charity in human life. The science taught is defined as knowledge that has been classified, organized, systematized, and interpreted, produces objective truth, has been tested for truth, and can be scientifically retested. Science in Islamic teachings has a classification and characteristics of Ilähiyah. Therefore, knowledge in Islam cannot be separated by faith, even it can be said that knowledge comes from Allah. God as a source of knowledge, educating humans through the verses of Allah, both written and implied in the Qur'an and the laws of sunnatulläh that are in nature (Ali, 2007).

However, the ultimate goal of Islamic education cannot be separated from the life purpose of a Muslim. Islamic education is a means to achieve the ultimate goal of human life as a form of human servitude towards God. The aim of Islamic education to be achieved must, of course, depart from the basic foundations of education in Islamic teachings, namely: integrity (syumüliab), integration, continuity, authenticity, practicality, solidarity, and openness. The most important thing is that educational goals can be translated operationally into syllabi and subjects taught at various levels of education (elementary, high schools, and higher education/ university), even at non-formal education institutions. Some characteristics of Islamic education (Azra, 1999), namely:

a. Mastery of science. The basic teachings of Islam oblige to seek knowledge for every Muslim. The Apostle sent by God was first equipped with knowledge, and they were instructed to develop that knowledge.

b. Development of science. The knowledge that has mastered must be given and developed to others.

c. Emphasis on moral values in mastering and developing knowledge. The knowledge gained from Islamic education is bound by moral values.

d. Mastery and development of science, only for devotion to God and public benefit.

e. Adjustment to child development. Since the beginning of the development of Islam, Islamic education was given to children according to age, abilities, mental development, and children's talents. Every effort and education process must pay attention to child growth factors.

f. Personality development. Natural talents and personal abilities of each student are given the opportunity to develop so that they are beneficial for themselves and the community. Every student is seen as God's mandate, and all physical and mental abilities are a gift from God. Personality development is related to the entire value of the Islamic system so that every child can be directed toward achieving the goals of Islam.

g. Emphasis on righteous deeds and responsibilities. Every student is given enthusiasm and encouragement to practice science so that it is truly beneficial for themselves, their families 
and society as a whole. It is charity and responsibility that brings it to happiness later in the day.

Islamic education has a direct bond with Islamic values and teachings that govern all aspects of its life. When the definitions of education associated with Islamic education, it will know that Islamic education emphasizes more on the balance and harmony of the development of human life. Islamic education is defined as an effort to change individual behavior in his personal life or social life, and life in the surrounding environment through the process of education. The change based on Islamic values, namely values that give birth to sharia norms and akblak karimah (Arifin, 2016).

Discussions about the purpose of education will discuss the function of education. The function of Islamic Education, for schools/ madrasah (Majid \& Andayani, 2004), namely:

1. Development and enhancement of the faith and devotion of students to Allah who have implanted in the family environment. The obligation is carried out by every parent in the family, including the development of literary culture. The school functions to foster faith and piety done by every parent in the family. The school serves to grow further in the child through guidance, teaching, and training so that faith and piety can develop optimally according to the level of development.

2. Value placement as a guide to life to seek happiness to live in the world and the hereafter.

3. Mental adjustment as a process of adjustment to the environment, both physical and social environment, and can change the environment by the values of Islam.

4. Correction of mistakes, shortcomings, and weaknesses of students in their beliefs, understanding, and experience of religious values in daily.

5. Prevention to counteract the negative things from their environment, or from other cultures that can endanger themselves and hinder their development as good human beings.

6. Teaching religious knowledge in general (real and non-real nature), system, and functional.

7. Distribution of children who have special talents in the field of Islamic religion so that these talents can develop optimally so that they can be utilized for themselves and others.

One factor that may influence learning activity is the external factors (Helmawati, 2014). An external factor is the state of the environment that can affect a person at the learning time. One of the influential environments is a family environment. As the research finding stated and by the above theoretical framework and it is seen that family is a factor that affects the learning motivation.

The development of the next research can then directed to the ability of technologybased literacy, especially multimedia-based learning. Multimedia is a digital product that presents and combines text, sound, images, animation, audio, and video, which implemented with tools and connections (link), so that users can navigate, interact, work and communicate (Sari, et al., 2018). In the world of education, multimedia is used as a teaching medium, both in class and individually (Farida, et al., 2018). Multimedia for the learning process has been proven capable of a pleasant learning atmosphere (Aisyah, et al., 2017), increase learning motivation (Sari, et al., 2017), learning effectivity (Irwansyah, et al., 2017), develop the level of understanding (Helsy, et al., 2017), students cantered learning, and investment efficiency of learning facilities (Irwansyah, et al., 2018).

\section{CONCLUSION}

Based on the research findings and discussion, it can be concluded that the culture of family literacy gave a positive and significant effect on the motivation of students in Islamic Education subject. School should pay attention to the cooperation of the education path 
(formal, informal and non-formal), in this case, is the cooperation between school and family in programs and activities that can improve student's learning motivation. As the fact that the educational goals can achieve by maintaining good cooperation between school and family. The school is expected to implement GLS (Gerakan Literasi Sekolah/ School Literacy Movement) so that the students' knowledge will widely improve because of reading. This can be a way to realize the good cooperation between school and student's family. When a family has a family literacy culture program, schools should apply GLS too.

To obtain optimal learning achievement, teachers are expected to maintain and improve student learning motivation. Students and family should grow literacy activity within their family. With a good culture of family literacy, it is expected to improve student's learning achievement optimally.

\section{BIBLIOGRAPHY}

Ainissyifa, H. \& Hamdani, F., 2012. Creating organizational culture to increase academic athmosphere in Higher Education Institute. International Journal of Islamic Khazanah, 1(1), pp. 1-12. Retrieved from https://bit.ly/2EZzu6W

Aisyah, R., Zakiyah, I. A., Farida, I. \& Ramdhani, M. A., 2017. Learning crude oil by using scientific literacy comics. Journal of Physics: Conference Series, 895(1), p. 012011. https://doi.org/10.1088/1742-6596/895/1/012011

Alvesson, M., 2002. Understanding organisational culture. London: Sage Publications.

Amin, A. S. \& Ramdhani, M. A., 2006. Konfigurasi model untuk sistem pendukung keputusan. Majalah Ilmiah Ekonomi Komputer, 16(1), pp. 11-19. Retrieved from https://bit.ly/2Q8Z76t

Arief, A., 2003. Pengantar ilmu dan metodologi pendidikan Islam. Jakarta: Ciputat Press.

Dalman, 2012. Keterampilan menulis. Jakarta: Raja Grafindo Persada.

Davis, K. \& Newstrom, J. W., 2004. Perilaku dalam organisasi. Jakarta: Erlangga.

Farida, I., Helsy, I., Fitriani, I. \& Ramdhani, M. A., 2018. Learning material of chemistry in high school using multiple representations. IOP Conference Series: Materials Science and Engineering, 228(2017), p. 012078. https://doi.org/10.1088/1757-899X/434/1/012053

Hamalik, O., 2010. Kurikulum dan pembelajaran. Jakarta: Bumi Aksara.

Harjasujana, A. S. \& Damaianti, V. S., 2003. Membaca dalam teori dan praktik. Bandung: Mutiara.

Hasbiyalloh \& Sulhan, M., 2015. Hadis tarbawi. Bandung: Remaja Rosda Karya.

Helmawati, 2014. Pendidikan keluarga. Bandung: Remaja Rosda Karya.

Helsy, I., Maryamah, Farida, I. \& Ramdhani, M. A., 2017. Volta-based cells materials chemical multiple representation to improve ability of student representation. Journal of Physics: Conference Series, 895(1), p. 012010. https://doi.org/10.1088/1742-6596/895/1/012010

Hofstede, G., 1980. Cultures consequences: International differences in work-related values. Beverly Hills: Sage Publications.

Hughes, D., 1996. NHS Managers as rhetoricians: A case of culture management?. Sociology of Health and Illness, 18(3), pp. 291-314. Retrieved from https://bit.ly/2EZzu6W

Irwansyah, F. S., Lubab, I., Ramdhani, M. A. \& Farida, I., 2017. Designing interactive electronic module in chemistry lessons. Journal of Physics: Conference Series, 895(1), p. 012009. https://doi.org/10.1088/1742-6596/895/1/012009

Irwansyah, F. S., Yusuf, Y. M., Farida, I. \& Ramdhani, M. A., 2018. Augmented reality (AR) technology on the android operating system in chemistry learning. IOP Conference Series: Materials Science and Engineering, 288(2017), p. 012068.

Kementerian Pendidikan dan Kebudayaan, 2016. Buku saku gerakan literasi sekolah. Jakarta: Kementerian Pendidikan dan Kebudayaan.

Kern, R., 2000. Literacy and language teaching. Oxford: Oxford University Press. 
Laila, I. N., 2016. Menyayangi anak sepenub hati. Solo: Ira Adi Citra Intermedia.

Morgan, G., 1997. Images of organization. Newbury Park, CA: Sage.

Mulyana, S., 2009. Teori pendidikan Islam. Pustaka Bhakti Negeri: Bandung.

Nurfajrinah, M. A., Nurhadi, Z. F. \& Ramdhani, M. A., 2017. Meaning of online shopping for indie model. The Social Sciences, 12(4), pp. 737-742. https://doi.org/ 10.3923/sscience.2017.737.742

Permatasari, A., 2015. Membangun kualitas bangsa dengan budaya literasi. Bengkulu, Universitas Bengkulu, pp. 146-156.

Ramdhani, A., Ramdhani, M. A. \& Ainisyifa, H., 2017. Conceptual Framework of corporate culture influenced on employees commitment to organization. International Business Management, 11(3), pp. 826-803. https://doi.org/ 10.3923/ibm.2017.826.830

Ramdhani, A., Ramdhani, M. A. \& Amin, A. S., 2014. Writing a literature review research paper: A step-by-step approach. International Journal of Basic and Applied Science, 3(1), pp. 47-56. Retrieved from https://bit.ly/2Amodtx

Ramdhani, M. A., 2013. Metodologi penelitian dalam riset teknologi informasi. Bandung: UIN Sunan Gunung Djati Bandung.

Ramdhani, M. A., Djamaluddin, D. \& Ainissyifa, H., 2015. Building moderate attitude through character education. Songkla, Songkla University, pp. 791-798.

Ramdhani, M. A. \& Ramdhani, A., 2014. Verification of research logical framework based on literature review. International Journal of Basic and Applied Science, 3(2), pp. 11-19.

Ramdhani, M. A. \& Ramdhani, A., 2016. Penelitian pemasaran. Bandung: UIN Sunan Gunung Djati Bandung.

Robbins, S. P. \& Coulter, M., 2010. Manajemen. Jakarta: Erlangga.

Sareb, P. M., 2008. Menumbubkan minat baca sejak dini. Jakarta: Indeks.

Sari, S., Anjani, R., Farida, I. \& Ramdhani, M. A., 2017. Using android-based educational game for learning colloid material. Journal of Physics: Conference Series, 895(1), p. 012012.

Sari, S., Aryana, D. M., Subarkah, C. Z. \& Ramdhani, M. A., 2018. Multimedia based on scientific approach for periodic system of element. IOP Conference Series: Materials Science and Engineering, 288(1), p. 012137.

Soemanto, W., 2012. Psikologi pendidikan. Jakarta: Rineka Cipta.

Somadyo, S., 2011. Strategi dan teknik pembelajaran membaca. Yogyakarta: Graha Ilmu.

Sukmadinata, N. S., 2011. Landasan psikologi proses pendidikan. Bandung: Remaja Rosda Karya.

Sutrisno, E., 2010. Budaya organisasi. Jakarta: Kencana .

Tafsir, A., 2014. Ilmu pendidikan dalam perspektif Islam. Bandung: Remaja Rosda Karya.

Tampubolon, 1993. Mengembangkan minat dan kebiasaan membaca pada anak. Bandung: Angkasa.

Taniredja, T., Faridli, E. M. \& Harmianto, S., 2011. Model-model pembelajaran inovatif. Bandung: Alfabeta.

Tarigan, H. G., 2008. Membaca sebagai suatu keterampilan bahasa. Bandung: Angkasa.

Uno, H. B., 2011. Teori motivasi dan pengukurannya. Jakarta: Bumi Aksara. 